Meta

Journal des traducteurs

Translators' Journal

\title{
Translating for Children - World View or Pedagogics?
}

\section{Radegundis Stolze}

Volume 48, numéro 1-2, mai 2003

Traduction pour les enfants

Translation for children

URI : https://id.erudit.org/iderudit/006968ar

DOI : https://doi.org/10.7202/006968ar

Aller au sommaire du numéro

Éditeur(s)

Les Presses de l'Université de Montréal

ISSN

0026-0452 (imprimé)

1492-1421 (numérique)

Découvrir la revue

Citer cet article

Stolze, R. (2003). Translating for Children - World View or Pedagogics? Meta, 48(1-2), 208-221. https://doi.org/10.7202/006968ar

\section{Résumé de l'article}

Dans cet article, on discute de l'attitude du traducteur face à sa tâche. Dans une première analyse descriptive de plusieurs traductions allemandes d'une histoire italienne d'enfants, on détecte une tendance à simplifier la langue et, en même temps, à utiliser des surexplicitations. En argumentant à partir de la perspective du traducteur lui-même, on discute alors de la lecture experte nécessaire et de la compréhension herméneutique, ainsi que du problème de coordination des divers critères rhétoriques dans la production du texte. En s'appuyant sur la responsabilité sociale des traducteurs, on peut conclure qu'ils devront réfléchir à leurs choix en formulant ce qui a trait à la cohérence, au style et à l’idéologie. 


\title{
Translating for Children - World View or Pedagogics?
}

\author{
RADEGUNDIS STOLZE \\ University of Technology Darmstadt, Darmstadt, Germany \\ radi.stolze@t-online.de
}

\begin{abstract}
RÉSUMÉ
Dans cet article, on discute de l'attitude du traducteur face à sa tâche. Dans une première analyse descriptive de plusieurs traductions allemandes d'une histoire italienne d'enfants, on détecte une tendance à simplifier la langue et, en même temps, à utiliser des surexplicitations. En argumentant à partir de la perspective du traducteur lui-même, on discute alors de la lecture experte nécessaire et de la compréhension herméneutique, ainsi que du problème de coordination des divers critères rhétoriques dans la production du texte. En s'appuyant sur la responsabilité sociale des traducteurs, on peut conclure qu'ils devront réfléchir à leurs choix en formulant ce qui a trait à la cohérence, au style et à l'idéologie.
\end{abstract}

\begin{abstract}
This article discusses the translator's approach to the task of translating. In an initial descriptive analysis of several German translations of an Italian novel a tendency towards linguistic simplification and over-explicitation in view of easy reading can be detected. Switching the perspective to the translator's own dynamic view of text production, the necessary expert reading and hermeneutic understanding, as well as the coordination problem of various rhetoric criteria of writing are being discussed. Based on the translator's social responsibility we may conclude that translators should be aware of the problems arising and reflect consciously on their formulation decisions regarding coherence, style and ideology.
\end{abstract}

\section{MOTS-CLÉS/KEYWORDS}

translation for children, expert reading, quality assessment, ideology, formulation

\section{Simplified translation for children}

The starting point of an approach to translating for children is often a view of translation as rewriting for different audiences in different times, places, and cultures (Lefevere 1992). This includes an attitude geared towards the target language, culture and addressees that even is meant to influence the perception of the source text which has to be translated (Nord 1997). The idea is that in a text analysis only those aspects of the text should be detected and transferred, that seem to be adequate for the final translation purpose. In literary Translation Studies it has been taken for granted that "all translating implies a degree of manipulation of the source text for a certain purpose" (Hermans 1985: 11). And Lefevere (1992: 13) affirms: "Rewriters have to be traitors, but most of the time they do not know it and nearly all of the time they have no other choice." Venuti (1995: 93) sees everywhere some "asymmetrical relations" because all translations would be "fundamentally ethnocentric." 
This result may come up unconsciously in an ethnocentric approach, or intentionally in a reader-oriented attitude. And this seems particularly true regarding the translation for children, since those are widely seen to be different from adults in their capacity of understanding a text, perceiving pictures and strange words. However such a view can also be questioned from various perspectives.

First of all, the question should be raised whether children as audience really are so different from adults in their role of reading, hearing and understanding a text. Some translators argue that translating for children is not very different from translating for adults (Slatyer 2002). When children's books are being translated for children, the original content is already adapted to the world of thought of children. So the translation could focus on its task of presenting the original text in another language.

The flood of children's literature and of constantly new translations and rewritings of classical works, however, shows that this task is not seen as so easy as one might naively imagine. Studies have shown that there is a significant difference between the first, maybe official translation of a classical children's book, and later translations. It is common ground that the old German translation of Pipi Langstrumpf, which we all have read in our childhood, is said to be full of stylistic blunder but very witty, whilst a later translation being more faithful to the original is linguistically plain. In the same way it was shown that a recent translation of The Little Prince into English was purified of many strange expressions, old-fashioned words and interferences (Slatyer 2002). It was easier to understand. In interviews the subjects affirmed that the new translation was certainly better for the children. And which one would you prefer for yourself? Answer: the old one. When a mother made the test and read that text to her little daughter, she became aware that it really was nearly unintelligible and difficult to read, so full of strange and unsuitable expressions it was. But the child was marveled. And what did she like most: "the words," they must have seemed strange, phantastic and mysterious to her. There are also many retellings of old stories, and their tendency goes towards a simplification of the texts. Obviously we as adults seem to imagine our children gifted with only a limited capacity to understand texts.

For the purpose of this article I have compared several German translations of Carlo Collodi's famous story of "Pinocchio," the wooden puppet having to pass various adventures before becoming a real boy. And even here I could see a tendency going from a rather old-fashioned and very "free" translation towards modern translations in a simplified language, especially in short retellings of the story which cannot really be called a translation. Besides that, there are even television adaptations of the old story, and of course comics. Many translations also contain a lot of overexplicitation compared with the original text. The express purpose of new renderings is easy understanding, see for instance Audrey Daly (1979): "neu erzählt zum leichten Lesen" (retold story for easy reading).

The question is permitted whether we are not looking down on our children with our opinion that they cannot understand many things, forcing them into simple texts that have lost any feature of difficulty, foreignness, challenge and mystery. The prize for easy reading is not rarely boredom. 


\section{The story of Pinocchio}

However, the above statements require a closer look at various translations and the Italian original. I have no doubt that one could do the same comparison for English translations or even for those in another language. Pinocchio since its first edition in 1883 has been translated all over the world.

The Italian original by Carlo Collodi (1826-1890) first appeared between 1881 and 1883 in sequels in a children's magazine. After completion of the series, the first book-edition came out in 1883. However, only after 1914, when Paul Hazard called it a classical piece of Italian literature in the "Revue des deux mondes," it become famous and by 1937 there were already two hundred translations, but it was not before the fifties that the first of innumerable illustrated editions came out (Pagliari 1981: 10). In the following we will discuss some examples from the first German translation of 1913 (Trl-A) reprinted until the fifties, from a later one of 1965 ( $\mathrm{Trl}-\mathrm{B}$ ) and a recent one from 1988 (Trl-C), as well as a retelling (Daly 1979). Tlhe book begins:

(Original). I. Come andò che maestro Ciliegia, falegname, trovò un pezzo di legno, che piangeva e rideva come un bambino.

C'era una volta...

- Un re! - diranno subito i miei piccoli lettori.

- No, ragazzi, avete sbagliato. C'era una volta un pezzo di legno.

Non era un legno di lusso, ma un semplice pezzo da catasta, di quelli che d'inverno si mettono nelle stufe e nei caminetti per accendere il fuoco e per riscaldare le stanze.

Non so come andasse, ma il fatto gli è che un bel giorno questo pezzo di legno capitò nella bottega di un vecchio falegname, il quale aveva nome mastr'Antonio, se non che tutti lo chiamavano maestro Ciliegia, per via della punta del suo naso, che era sempre lustra e paonazza, come una Ciliegia matura.

Appena maestro Ciliegia ebbe visto quel pezzo di legno si rallegrò tutto; e dandosi una fregatina di mani per la contentezza, borbottò a mezza voce:

- Questo legno è capitato a tempo: voglio servirmene per fare una gamba di tavolino.

(Trl-A): Erstes Stück: Ein Holzscheit, das sprechen, lachen und weinen kann

Es war einmal...

„Ein König!“ - meinen gleich die klugen kleinen Leser.

Aber diesmal, Kinder, habt ihr weit daneben geraten. - Es war einmal: ein Stück Holz, ja ein ganz gewöhnliches Holzscheit! Draußen lag es im Wald mit vielen andern Stükken auf der Beige. Ein Fuhrmann kam, lud sie alle auf den wagen und fuhr damit zur Stadt dem Schreiner-Toni vor das Haus. Das Holz ward gesägt und gespaltet; denn im kalten Winter sollte es im knisternden Ofen die Stube wärmen. - Ein Glück, dass Toni das eine Scheit bemerkte. Es war so hübsch gerade und hatte keinen Ast; drum stellte es der Schreiner in eine Ecke seiner Werkstatt und dachte: „Ein gutes glattes Stück, 's wär' schade, es zu verbrennen."

Toni verstand sein Handwerk und war überall bekannt. - Man nannte ihn freilich nur den Meister Pflaum, doch das kommt davon, daß seine zierliche runde Nasenspitze so duftig blau erglänzte wie eine reife Pflaume, die unberührt am Baume hängt.

Eines Tages war Meister Pflaum daran, einen Tisch zu verfertigen. Eben sah er sich in der Werkstatt nach dem passenden Holze um, erblickte das Scheit in der Ecke, rieb sich freudig die Hände und murmelte zufrieden vor sich hin: „Das Stück da kommt mir wie gerufen, es gibt einen Tischfuß."

Trl-A though designed as a translation in the foreword, transfers the whole story into a southern German rural environment described explicitly. The dialect shows in 
words like Bengele, Beige, Stube, Scheit, Schnefler, Gälfink, etc. Even if it follows the various chapters, the respective titles are not translated literally and there are explanatory additions. The translator sees the need to explain several things and thus the story gets much longer than the original. The names are also changed: Antonio $\rightarrow$ Toni, maestro Ciliegia $\rightarrow$ Meister Pflaum, compar Geppetto $\rightarrow$ Meister Seppel. Later translations stick more closely to the original in a more or less literal translation, but not doing without over-explicitation as well. They even use a less solemn, more neutral language.

(Trl-B): I. Kapitel: Wie es zuging, dass Meister Kirsche, der Tischler, ein Stück Holz fand, das wie ein Kind weinen und lachen konnte.

Es war einmal...

„Ein König!“, werden sofort meine kleinen Leser rufen.

Nein, Kinder, da habt ihr euch geirrt! Es war einmal - ein Stück Holz. Es war gar kein besonderes Holz, sondern ein ganz gewöhnliches Stück Brennholz, wie man es im Winter in den Ofen oder in den Kamin steckt, um Feuer anzuzünden und die Stube zu heizen.

Ich weiß nicht, wie es zuging, aber Tatsache ist, dass dieses Stück Holz eines schönen Tages in die Werkstatt eines alten Tischlers geriet. Der Tischler hieß Meister Antonio, aber alle nannten ihn nur Meister Kirsche, weil seine Nasenspitze immer rot war und wie eine reife Kirsche leuchtete.

Sobald Meister Kirsche dieses Stück Holz entdeckte, wurde er ganz vergnügt. Er rieb sich vor Freude die Hände und brummelte vor sich hin: „Dieses Holz kommt wir wie gerufen, ich werde ein Tischbein daraus machen."

(Trl-C): Kapitel I. Wie es kam, dass Tischlermeister Kirsche ein Stück Holz fand, das wie ein Kind weinte und lachte.

Es war einmal...

„Ein König!“ werden gleich meine kleine Leser sagen. Nein, ihr Kinder, diesmal habt ihr nicht recht.

Es war einmal ein Stück Holz.

Es war kein edles Holz, nur ein einfaches Stück Brennholz, wie man es im Winter in die Öfen und Kamine wirft, um Feuer zu machen und die Zimmer zu heizen.

Ich weiß nicht, wie es kam, jedenfalls landete dieses Stück Holz eines schönen Tages in der Werkstatt eines altern Tischlers, der Meister Anton hieß, den aber alle Meister Kirsche nannten, weil seine Nasenspitze immer so dunkelrot glänzte wie eine reife Kirsche. Kaum hatte Meister Kirsche das Stück Holz gesehen, freute er sich sehr, rieb sich zufrieden die Hände und murmelte leise vor sich hin: „Dieses Holz kommt mir gerade recht, Ich will ein Tischbein daraus machen."

While Trl-A is totally geared towards a German child language, the second Trl-B is rather the opposite. It sticks literally to the original wording sometimes, however, over-interpreting the allusions. In both versions much of the original linguistic wittiness is lost:

(Orig.) - Buon giorno, mastr'Antonio disse Geppetto. - Che cosa fate costì per terra?

- Insegno l'abbaco alle formicole.

- Buon pro vi faccia.

- Chi vi ha portato da me, compar Geppetto?

- Le gambe. Sappiate mastr'Antonio, che son venuto da voi, per chiedervi un favore.

- Eccomi qui, pronto a servirvi, - replicò il falegname, rizzandosi su in ginocchi. 
(Trl-A) „Guten Tag, Meister Toni!” grüßte Seppel artig, „was schaffst du denn auf dem Boden?" „Ich will den Ameisen das ABC beibringen.“ „Ein neuer Beruf! - Guten Erfolg!"

"Was bringt dich heute zu mir, Seppel?"

„Eine kleine Sorge Toni; ich möchte dich um einen Gefallen bitten. - Heute früh ist mir ein neuer Gedanke in den Kopf gekommen."

„Laß hören!" sagte der Schreiner und stand vom Boden auf.

(Trl-B) „Guten Tag Meister Antonio! „sagte Geppetto. „Was macht Ihr denn da unten auf der Erde?"

„Ich bringe den Almeisen das Rechnen bei.“

„Ich wünsche Euch viel Vergnügen!“

„Was führt Euch zu mir, Gevatter Geppetto?“

„Meine Beine! -Wisst Ihr, Meister Antonio, ich bin hergekommen, um eine Gefälligkeit von Euch zu erbitten."

„Hier bin ich und stehe zu Diensten“, erwiderte der Tischler und richtete sich auf den Knien auf.

(Trl-C) „Guten Tag, Meister Anton“, sagte Geppetto. „Was macht Ihr denn dort auf dem Boden?"

"Ich bringe den Ameisen das Einmaleins bei."

„Na dann viel Spaß!“

„Wer hat euch zu mir gebracht, Gevattter Geppetto?“

„Die Beine! - Hört, Meister Anton, ich bin gekommen, um euch um einen Gefallen zu bitten.“

„Bitte sehr, ganz zu Euren Diensten“, antwortete der Tischler, der jetzt kniete.

The joke is better rendered in Trl-C. This version also very well enables a visionary imagination of the given situations. This is reached by more concentrated formulations, whilst Trl-B formulates a bit clumsily. Example:

A sentirsi chiamar Polendina per la terza volta, Geppetto perse il lume degli occhi, e si avventò sul falegname; e lì se ne dettero un sacco e una sporta.

A battaglia finita, mastr'Antonio si trovò due graffi di più sul naso, e quell'altro due bottoni di meno al giubbetto. Pareggiati in questo modo i loro conti, si stinsero la mano e giurarono di rimaner buoni amici per tutta la vita.

(Trl-B) Als Geppetto sich zum dritten Male Strohkopf nennen hörte, verlor er die Beherrschung und stürzte sich auf den Tischler und dann verprügelten sie sich nach Strich und Faden.

Als die Prügelei zu Ende war hatte Meister Antonio zwei Kratzer mehr auf der Nase und der andere zwei Knöpfe weniger an der Jacke.

Da sie auf diese Weise ihre Rechnung beglichen hatten, drückten sie sich die Hände und schworen, ihr ganzes Leben lang gute Freunde zu bleiben.

(Trl- C) als Geppetto sich zum dritten Male ,Maisbrei' nennen hörte, sah er rot.

Er stürzte sich auf den Tischler, und nun verprügelten sie sich nach allen Regeln der Kunst.

Nach der Schlacht hatte Meister Anton noch zwei Kratzer mehr auf der Nase und der andere zwei Knöpfe weniger an seiner Jacke. So waren sie quitt; sie schüttelten sich die Hände und schworen bis an ihr Lebensende gute Freunde zu bleiben.

We generally observe that the $\operatorname{Trl}-\mathrm{C}$ is best suitable to be read to children. Both Trl-B and C are literal, but Trl-B is very anxious to achieve a fluent style, realized mostly in relative and sequential sentences. This leads to a high reading speed skimming 
through the text. Also it uses official dictionary translations, e.g., Marionette (burattino, Holzpuppe), Gendarm (carabiniere, Polizist Schutzmann), Berberross (barbero, Araberhengst) that are probably beyond childrens language.

The battle between Antonio and Geppetto is eliminated in Trl-A and Daly, because it was considered secondary to the overall story of Pinocchio's adventures.

(Daly 1979) Dies ist die merkwürdige Geschichte eines Stückes Holz, das erst eine Puppe und dann ein wirklich lebender Junge wurde!

Alles begann, als Antonio der Tischler ein Stück Holz vom Stapel aus der Ecke seiner Werkstatt nahm. Es war ein ganz gewöhnliches Stück Holz und gar nichts besonderes. Als dann Antonio sein scharfes Beil hob, um die Rinde abzuschälen, sagte eine feine Stimme ... (4).

The modern retelling keeps the names (Antonio, Geppetto) but eliminates all descriptive features of the story. Like in a summary only the various adventures are related, sometimes even connected in a rather illogical way. The result of the story is given right in the beginning (und dann ein wirklich lebender Junge wurde) thus taking away all interest for the end. Besides these initial remarks on antiquated or modern wording, on fluent or clumsy style, there are more decisions from the translator's competence which need precise categories to be analysed.

\section{The hermeneutic problem}

In focusing on the target conditions of a translation, for instance the suitability of a text for children, the problem of understanding the source text is easily neglected. There is a significant difference between interpreting as an oral reproduction of speech heard, and translation as a presentation of written texts in intercultural communication. In speech acts with a shared presence of speaker and audience, speakers may well negotiate their text understanding with others according to relevance, as they mutually share the same cognitive environment and situation (Gutt 2000: 32).

A written text however is a means of carrying information fixed in the language, into other times, places and cultures for unknown readers. Written texts are severed from their original situation. In understanding such texts this "situation" can only be reconstructed by the fact that the textual input creates a cognitive scene in the reader's and the translator's mind (Fillmore 1977: 63). Even if texts may materially "transfer" information between cultures, this information is "revived" in the relationship between reader and text, as it induces a cognitive representation. Texts allow us to view beyond the text structures into a distant external world.

The identification of a specific subject from a visual scene is one of the most important comprehension tasks in written texts. There is the risk for the unprofessional reader and translator to infer inadequate text meanings, because there is no situation shared to enact the principle of relevance. Therefore the translators' orientation in the world and their textual approach as readers are a central issue. Comprehending a text creates a mental representation which will then be presented in the translation. Both texts together - the original and the translation - are the same, an external form of the cognitive representation of the message. The relation is between the translator and the message, and not between two texts in different cultures.

Texts carry messages from authors, but they have lost the direct stimulus character of utterances, they are now open to various interpretations, and the readers and 
particularly translators have to reflect on their understanding. Comprehension is never a matter of fact. There is no partner to negotiate the sense, but the text remains present for repeated reading. Initial inference of a supposedly relevant information may later prove inadequate and be transformed during the whole reading process.

The translator's approach may be based on hermeneutics (Stolze 1992: 49). Hermeneutics as a language philosophy discusses the possibility of understanding foreignness, for instance strange or unconventional aspects in texts. However, this also includes the reader himself. What perhaps is difficult to understand for me might be totally clear for another reader, who had traveled the country and already seen certain things, or knows his author, or has access to the respective domain of science. What I understand depends on what I know already. The main problem in translation therefore is the translator's knowledge base and ideology as a person, that will be activated by the textual input. This is the hermeneutic problem.

\section{Expert reading as a translator}

The translator does not stand in between two cultures, but he or she is rooted in one culture, and by having access to the other, s/he has cognitively a part in both. The two culture systems make contact within his or her mind, in other words: the translator's cognition as an expert reaches out into two different cultures, and into various discourse fields of scientific and academic knowledge. Such translation competence in reading - dependent on one's knowledge - is adapted to practice, for instance in the translation industry, where we are constantly faced with different texts.

The necessary "expert reading" by a translator means firstly an expert "positioning" of the text in its culture, discourse field and concepts, and this will activate the given knowledge base regarding cultural characteristics and features of specialist communication, as they are reflected in the texts. All texts include general language and specialist language features, but to a varying degree. Language is a means used for many different purposes, and the words themselves do not show their background. They only get their real meaning when seen against that background and within a text. In the process of understanding, we will have to consider the text as a whole. Initially we will only get an individual understanding of a text and need further corresponding research before we may be able to present the message responsibly. Later on, the professional translator has acquired more routine and will be able to infer the relevant knowledge right from the beginning. Thus the translator has a double perspective on texts: viewing their cultural embedding and analyzing the text structure to find confirmation for the initial intuitive understanding.

The holistic approach to texts in literature and in specialist communication is the same, but the required knowledge base is different. In general language texts and literature, we should observe the social place of a group and the rooting of people, as a culture is no homogeneous entity. Every field of communication has its specific concepts and they recur in the texts. The author's ideology is decisive for understanding the text and its intention. We should know about cultural associations and metaphors representing stereotypes. The aspects to be considered in translational expert reading are shown in the table: 


\begin{tabular}{|l|l|l|}
\hline $\begin{array}{l}\text { Translational } \\
\text { expert reading }\end{array}$ & literature & specialist texts \\
\hline culture & people, country & $\begin{array}{l}\text { area of research and work } \\
\text { (science, humanities) }\end{array}$ \\
\hline discourse field & $\begin{array}{l}\text { social background \& field } \\
\text { of communication, } \\
\text { author's ideology }\end{array}$ & $\begin{array}{l}\text { discipline \& domain, level of } \\
\text { communication }\end{array}$ \\
\hline concepts & $\begin{array}{l}\text { cultural associations, key words, } \\
\text { stereotypes }\end{array}$ & $\begin{array}{l}\text { terminological conceptualization } \\
\text { (definition/deduction vs. convention/ } \\
\text { interpretation) }\end{array}$ \\
\hline
\end{tabular}

This can be applied to our example of Carlo Collodi's Pinocchio. It should be noted that the story originally was severed into various sequels. It was not a totally harmonious entity as a whole story.

This may explain the fact that in Daly's (1979) retelling the different adventures are put one after the other, not appearing very logical and only linked by some banal remarks: aber grade in diesem Augenblick kam sein Freund Gepetto an die Tür (7). Sobald er das Gesicht der Puppe anfertigte (8). Geppetto ging mit ihm (dem Stück Holz) froh davon und begann sofort mit der Herstellung seiner neuen Puppe (9).

In Trl-A the arrangement with the chapter introductions has been changed to a sort of conclusion, while the other two translations return to the literal version. Daly's version, that actually seems to be a nameless German translation of an English language retelling, has no paragraph titles but it brings an abstract of the whole story right at the beginning, as already mentioned.

Pinocchio was written in Italian Florence evoking a rural environment of poor craftsmen after 1830, when the author was a child (Paglieri 1981: 17). His intention had been to write a story for children, in order to educate them by entertaining them. He had already earlier written various similar stories in children's journals which at the time were a pedagogic means. He wrote the story at the age of 55, at first reluctantly upon request of the editor, after he had been a journalist with originally democratic and liberal opinions, and later a more conservative attitude, after the unification of Italy.

The cultural associations show in aspects of the simple life of craftsmen in Italy: mascherone da fontana (ch. I), buscarmi un tozzo di pane e un bicchier di vino (ch. II). La casa di Geppetto era una stanzina terrena, che pigliava luce da un sottoscala (ch. III). These rather unspecific hints could have easily been transferred into German descriptions, e.g. Wasserspeier, mir mein Brot verdienen, Licht von einem Kellerfenster erhalten. But the translators put much effort in explaining: Trl-A Wasserspeier am Springbrunnen, verdiene mein Brot; hatte ein einziges Fenster. Trl-B Fratze eines Wasserspeiers am Brunnen; um mir mein Stück Brot und mein Glas Wein zu verdienen. Das Licht nur von einem Raum unter der Treppe erhielt. Trl-C Brunnenfigur; um mir damit ein Stück Brot und ein Glas Wein zu verdienen. Dessen Licht aus einer Besenkammer kam.

They had even more problems with the metaphor of Geppetto's yellow wig (ch. II): lo chiamavono col soprannome di Polendina, a motivo della sua parrucca gialla che somigliava moltissimo alla polendina di granturco. It looked like mush, obviously a typical Italian food. The translator will have to decide whether he conceives this intelligible by his target children, or whether it has to be changed, as in our examples: Trl-A Sie 
hießen ihn nur den, Gälfinken.' Seine gelbe Perücke hatte diesen Übernamen verschuldet. Trl-B riefen sie ihn bei seinem Spitznamen „Strohkopf," wegen seiner gelben Perücke, die tatsächlich dem Maisstroh sehr ähnlich sah. Trl-C riefen sie ihn mit seinem Spitznamen ,Maisbrei,' weil nämlich seine gelbe Perücke tatsächlich wie Maisbrei aussah.

In specialist communication we ask: which area of research and work - science or humanities - determines the discourse field of the text? We should know about the characteristics of specialist texts, that there are various disciplines with several domains, and that communication here functions against a specific background. There is the difference in terminological conceptualization between both exact definitions with methodical deduction in the sciences, and academic convention and interpretation of terms from humanities (Stolze 1992: 155). In our example, the use of specialist terminology is reduced to allusions to the carpenter's handicraft and other works.

\section{The coordination problem in translational text production}

In understanding a text in view of its culture, discourse field and important concepts the translator creates a global cognitive plan for the given task of presenting the message. Creating presence for that message understood by expert reading then means a "good text production." Whilst comprehending competence is organized rather globally, as it does not focus on grammar structures but creates a cognitive scene (Fillmore 1977: 63), productive competence really focuses on the text level, regarding formulation aspects in all detail (Antos 1982: 119).

Many researchers even view text production as a "problem solving process," following the studies of Hayes \& Flower (1980) who had verified the process of professional text production, defining the phases of planning, e.g., tentatively translating one's ideas into text structures, and reviewing the solutions according to communicative goals. In a cyclical movement, draft writing and reviewing are repeated several times, until a final text is produced that corresponds to the initial writing goal. In translating, this goal is given in the task of presenting the original message.

The problem-solving process of writing is oriented holistically towards the whole of a text. The initiative for producing a text is an overall idea, or a message understood from a translation original, and the writer intends to present that message. Writers dispose of global structures as a kind of "production scheme" for their process (Antos 1989: 21) focusing on pragmatic features such as intelligibility and functionality of the text, with the aim of a responsible presentation of the message in solidarity. In practice this proves to be a process of coordinating writing goals on the macro and micro levels of the texts. You need some awareness of genre norms, as they are cognitive formulation schemata and represent the utilization of already solved and socially accepted writing problems in certain recurrent situations. In our example the text even plays with the well-known genre norm of a story: C'era una volta. - Es war einmal.

The specific problem in translatoric text production is the coordination of the various rhetoric features that contribute to the intended meaning of the text as a whole. Such features are designed gradually in a constant reviewing and reformulating of the first draft, and they concern concrete aspects like text organization, adequacy for addressees, effect, style, emotion, institutional background, aesthetics, thematic 
progression, coherence, etc. on the text's macro level. All these global features can be described and are being constituted by rhetoric and stylistic forms on the micro text level. Formulaic writing with fixed blocks and phraseological elements represent the structure of text types against an institutional background what is particularly important in communication for specific purposes. On the other hand, in literary texts there is often an individual creative language to answer the very subjective questions of a poet. The difference between both forms of language usage is described as "sociologically varying usage of formulaic and unique language" (Antos 1982: 119; my translation). I already mentioned the linguistic wit of Carlo Collodi as insufficiently preserved in the translations.

In order to make the initial draft of the translation more precise and adequate for possible readers, it will be revised in several stages, according to quality assessment categories that are presented below. The individual coordination hierarchy of the various aspects has to be determined in every case of translation anew, there is no general rule for that. The translator will determine what appears to be the most important characteristic of a text. The revision of translation drafts may be based on linguistic aspects, as the translation task in the final instance is language production.

\section{Quality assessment categories}

The formulating problems can be described by rhetoric and stylistic categories. On the macro level there is first the writing category of semantics regarding world fields, compatibility and equivalence of terminology. A key to finding adequate formulations is the subject treated, which reflects in a semantic web of repeated words, or in the terminology. A coherent text normally has a theme appearing in a network of semantic relations (Weinrich 1976: 14). Their description provides the translator with an ensemble of context-specific semantic strategies for presenting the meaning of the text often already indicated in the title. A first step for reviewing the translation could be to find out a word field or a semantic axe of repetition and to search for corresponding lexemes in the other language. Visual imagination helps in that process. When you know what you want to say, you will also find the words. Semantic compatibility in collocations is also important to preserve the idiomatic coherence of a text, thus enabling the creation of an overall cognitive scene. In view of the text's cultural embedding one may also consider any typical association or stereotypes connected with central concepts in the text. Inter-textual relations to other texts may offer formulation models. It is the translator's decision where he or she sees the need for deeper explanation.

In communication for specific purposes the equivalence and consistence of the specific terminology is crucial. In the sciences, exact terms are often defined by deduction within a scientific system creating even new words. In humanities, the terms often come from general language words carrying a conceptual specification in the domain which has been found by academic convention. Translators will have to check the status of equivalence in scientific terms, or interpret the specialist hermeneutics of a text in humanities. One should also observe the language-typical forms of terminological word compounding, as special concepts are being expressed in special frames. 
There should be observed the text function as well, as it is part of the author's intention to be presented in the translation. It shows in the particular style of the text characterizing its author. Discourse markers may structure the message, the speaker's perspective ( $I$, we, anonymous one) is decisive, as well as the tense used (Stolze 1992: 238). Past tense for instance characterizes stories, whilst present tense is a signal of argumentation. Any inter-lingual grammar difficulties cannot be a motivation for changes. In LSP texts we have certain text types as cognitive models of formulation, which may be used in the translation independently from the original text-structure. Competent translators know about certain macrostructures and apply them, as they correspond to the addressees' reading expectations in the respective discourse field. Their level of comprehension determines the text arrangement. It is a difference whether you write for laymen or for specialists, intelligibility is a relative concept, but the translation is either an academic text or a text easy to understand for more people.

On the micro level, every text also shows a certain predicative mode. There are idioms and phrases that should find adequate correspondence in the translation, since mood and focusing in the sentence perspective tell us something about what was important to the author and what not. Any text element, however, has its meaning only in relationship to the overall sense of the whole text. Quotations in literature should be respected and checked carefully. In this respect our translation examples all more or less respect their original. In LSP texts we observe verbal speech acts indicating e.g., directives or legal obligations, and terminological phraseology. Passive voice often characterizes official texts and must not be eliminated in translations for so-called reasons of easier understanding. LSP texts are informative, anonymous and linguistically economical. They only use a functional part of the entire creative potential of a language.

The translatoric category of stylistics points to rhetorical means like expressive forms in literary texts or publicity, rhymes, alliteration, word metaphors, etc. In poetic texts all those forms are expressly and individually set, they should not be neglected, if a translation is also meant to be a poetic text. I mentioned the problem of jokes in our text. The point is not to copy such features, as this is often impossible for the differences between languages. But a sensitive translator detecting them will also find a solution. In LSP texts we have the features of a special functional style, standard formulae and text components according to the genre norm, sometimes even Controlled Language, with its rules to be used in the translation. Particularly language control is determined to produce intelligible texts. In this sense translators using Controlled Language could even correct defective source texts, e.g., in instruction manuals. Some of the main features are: use of familiar words, short sentences, linear text structure, no terminological synonyms, instructions in direct imperative.

Finally, the shape of the text plays a role. In concrete poetry for instance we may see the text arranged in a special form, there is rhythm, prosody, verse order or even pictures added. In LSP texts the internal relationship to illustrations and the layout prerequisites often are a special writing problem. Formatting organizes the text. Script fonts and structuring signs, however, may have a different appeal in various cultures. A survey of the quality assessment categories of text production is given in the table below. 


\begin{tabular}{|l|l|l|}
\hline Rhetorical categories & General language & LSP \\
\hline Semantics & $\begin{array}{l}\text { Semantic web, titles, } \\
\text { compatibility, pattern axes, } \\
\text { intertextuality }\end{array}$ & $\begin{array}{l}\text { Equivalence of terminology, } \\
\text { specification of concepts, } \\
\text { word compounding }\end{array}$ \\
\hline Text function & $\begin{array}{l}\text { Discourse markers, speaker's } \\
\text { perspective, tense, genre }\end{array}$ & $\begin{array}{l}\text { Text types, macrostructure, } \\
\text { addressees' expectation }\end{array}$ \\
\hline Predicative mode & $\begin{array}{l}\text { Idioms, mood, focusing, } \\
\text { quotations }\end{array}$ & $\begin{array}{l}\text { Speech acts, phraseology, passive } \\
\text { voice }\end{array}$ \\
\hline Stylistics & $\begin{array}{l}\text { Formal means, rhyme, } \\
\text { metaphors, alliteration }\end{array}$ & $\begin{array}{l}\text { Functional style, standard } \\
\text { formulae, controlled language }\end{array}$ \\
\hline Shape & $\begin{array}{l}\text { Rhythm, prosody, text form, } \\
\text { pictures, verse order }\end{array}$ & $\begin{array}{l}\text { Formatting, illustrations, } \\
\text { layout, script fonts }\end{array}$ \\
\hline
\end{tabular}

In the revision of an initial translation draft, all the mentioned categories play an important role, and they are interrelated and never equally valid. The translator will have to decide in each individual assignment which aspect is dominant. Multifaceted texts include all those aspects on varying levels of their holistic integrity. We will have to make a hierarchy, as the potential of various languages is different. This brings us to a last issue, as the translator is responsible for his or her formulation.

\section{Ideology in translations}

In this article I have combined descriptive and hermeneutic considerations. Descriptively we can see that there are different translations, according to the general world view, the zeitgeist of an epoque, or the translator's assumption regarding the addressees.

But as translators faced with the task of writing a translation from a given text, we have to ask ourselves and decide in which way we will present that message understood. In translating for children there is also the question about pedagogics as an overall goal of text production. What kind of world view do we want to impose on children responsibly? It is a question of ethics whether one will simply represent a given text by a faithful translation. Again we can look here at our example of Pinocchio.

As our text analysis on culture has shown, the original was written in the 19th century with a clear pedagogical view: children must observe their parent's orders, otherwise they will have many bad experiences. Ch. IV: Guai a quei ragazzi che si ribellano ai loro genitori e che abbandonano capricciosamente la casa paterna. Non avranno mai bene in questo mondo; e prima o poi dovranno pentirsene amaramente.

This kind of traditional pedagogics today is no longer seen as adequate for young people who should rather be educated to become self-confident, democratic and critical persons. From this conviction any changes in the story told for the children may be backed-up with the ethics of a modern pedagogics.

In the translation examples mentioned above this problem can be observed. In Trl-A which was written in the twenties in Germany, still the old-fashioned pedagogics of obedience was valid. Therefore these features in the journal text are all kept much in 
detail and even reinforced. This is not only to be seen in the hierarchical language: "Meister Pflaum" which indicates the superiority of the older man and creator of the puppet, but also in the entire structure of the story.

All the adventures Pinocchio has to undergo are in the original caused by his acts of disobedience. Several times he has to learn painfully what comes from doing the wrong things and not listening to the good voices. The story actually is a story of learning, of finally growing to be a responsible person. The young readers may draw this conclusion by themselves. While we do not find the terms ubbidienza, disubbidienza in the original, they a recurrent in Trl-A: (ch. 4) Schlecht geht es allen Kindern, die nicht auf ihre Eltern hören und eigenmächtig aus dem Hause laufen. Sie rennen ins Unglück und müssen einmal ihren Ungehorsam bereuen. While the original ends: com'ero buffo, quand'ero un burattino! E come ora son contento di essere diventato un ragazzino perbene! (= how funny I was as a puppet. Now I am happy that I became a real boy), Trl-A ends with a pedagogical warning: „Wie dumm daß ich so lange ein Hampelmann gewesen bin! - Nun aber will ich ein braver Knabe bleiben, und ich rate aeeln unartigen Kindern: spielt nicht den hölzernen Hampelmann!"

This basic ideological feature of Trl-A recurs even in the semantic web of the names: Pinocchio is called Bengele, Schlingel, Hampelmann which all have a negative connotation of "bad boy." The boys irritating Geppetto (I ragazzi del vicinato) are called here die bösen Buben. (Trl-B Die Kinder aus der Nachbarschaft; Trl-C Die Jungen aus der Nachbarschaft). Instead of tearing Pinocchio at the ears (dargli una buona tiratina d'orecchi, ch. III) which then prove not to be there because he had forgotten to carve them, we read in Trl-A about eine kräftige Ohrfeige geben (box round the ears). The more recent translations $\mathrm{B}$ and $\mathrm{C}$ of course keep here to the literal.

The aspects of disobedience are a bit drawn back there. Instead the aspects of adventure, of the learning experience, which is also included in the story for the child, are more stressed here. Courage in the hard experiences, curiousness and learning from one's errors are now seen as more important.

In Trl-C Pinocchio's intention to catch butterflies and rob nests (ch. IV: correre dietro alle farfalle e ... prendere gli uccellini di nido) is suppressed. This today is conceived as totally unacceptable for children, while in Trl-B and Trl-A it still reappeared.

In Daly 1979, all the parts regarding veneration of the elder generation, obedience or a moralizing undertone have disappeared. Instead the idea that one has to work in order to earn one's own living is stressed very much: Ich will auch nicht arbeiten. Alles, was ich mir wünsche, ist, viel Spaß zu haben (14). And it ends: Nun arbeitete Pinocchio fleißig... so wurde er schließlich ein wirklicher lebender Junge.

We may conclude that translators and storytellers should be aware of and reflect on the problems inherent in their work. Translation is not only a question of language transfer, of easy reading and of old-fashioned or modern wording. Even ideology reflects in the formulations. Translation is a question of understanding the text and the cultural background, and of deciding about the concrete language formulations to be used that imply decisions on coherence, style and ideology.

\section{REFERENCES}

Antos, G. (1982): Grundlagen einer Theorie des Formulierens. Textherstellung in geschriebener und gesprochener Sprache. Tübingen: Niemeyer.

Antos, G. (1989): „Textproduktion: Ein einführender Überblick.“ In Textproduktion. Ein interdisziplinärer Forschungsüberblick. G. Antos and H. P. Krings (eds.), 5-57. Tübingen: Niemeyer.

Beliebte Märchen: Pinocchio, von Carlo Collodi, neu erzählt zum leichten Lesen von Audrey DALY, illustriert Martin Aitchison. @ Ladybird Books Ltd. 1979, @ dieser Ausgabe 1993 by Tosa Verlag, Wien. (Daly 1979) 
Collodi, C.: Le avventure di Pinocchio a cura di Marina Taglieri con i disegni originali di Enrico Mozzanti e Sette note di Carlo Fruttero e Franco Lucentini, 1981, Milano: Mondatori, IV ristampa 1993. (Orignal)

Collodi, C.: Die Geschichte vom hölzernen Bengele. Ins Deutsche übertragen von Anton Grumann, 1913. 57. Aufl. 1950 Mit vielen farbigen Bildern von Wolfgang Felten. 91. Aufl. 1977, Freiburg: Herder. (Trl-A)

Collodi, C.: PINOCCHIO. Deutsch von Paula Goldschmidt. Illustrationen von Thorsten Tenberken, 1965. Berlin: Der Kinderbuchverlag. Neudruck 2002, Hamburg: Cecilie Dressler Verlag. $(\operatorname{Tr} l-B)$

Collodi, C.: pinocchios abentEuer. Deutsch von Hubert Bausch, illustriert von Robert Innocenti. @ der Übersetzung 1986 by Ph. Reclam, Stuttgart. @ 1988 für Text, Illustrationen und Ausstattung by Verlag Sauerländer Aarau/Frankfurt am Main. (Trl-C)

Fillmore, C. J. (1977): “Scenes-and-frames-semantics.” In: A. Zampolli (ed.). Linguistic Structures Processing. Amsterdam: New Holland, 55-81.

GutT, E.-A. (2000): Translation and relevance. Cognition and context. Manchester: St. Jerome.

HaYes, J. R. and L. S. Flower (1980): "Identifying the organization of writing processes." In: L. W. Gregg and E. R. Steinberg (eds.). Cognitive Processes in Writing. Hillsdale: Erlbaum, 3-30.

Hermans, T. (ed.). (1985): The Manipulation of Literature. Studies in Literary Translation. London/Sydney: Croom Helm; New York: St. Martin's Press.

Lefevere, A. (1992): Translation, Rewriting, and the Manipulation of Literary Fame. London and New York: Routledge.

NorD, C. (1997): Translating as a purposeful activity. Functionalist Translation Theories Explained. Manchester: St. Jerome.

Slatyer, H. (2002): The translator's choice: bringing the Little Prince to life. Poster at the XVI. World congress of F.I.T. "New Ideas for a New Century," 7-10. Aug 2002, Vancouver, Canada. (unpublished)

Stolze, R. (1992): Hermeneutisches Übersetzen. Linguistische Kategorien des Verstehens und Formulierens beim Übersetzen. Tübingen: Narr.

Venuti, L. (1995): The Translator's Invisibility: A History of Translation. London/N.Y.: Routledge. Weinrich, H. (1976): Sprache in Texten. Stuttgart: Klett. 